\title{
The Rationality of Antibiotics Use on Inpatient Department of Pediatric in One of the Hospital in Cimahi
}

Vina Septiani* ${ }^{*}$
Pudjiastuti Kartidjo ${ }^{2}$
Fenny Asri Nurdiani ${ }^{2}$
1Department of Pharmacy, Universitas
Jenderal Achmad Yani, Cimahi, West
Java, Indonesia
2Pharmacist Profession Study Program,
Universitas Jenderal Achmad Yani,
Cimahi, West Java, Indonesia
*email: vinaseptiani@gmail.com
Keywords:
Antibiotic
Pediatric
Rationality

\begin{abstract}
The purpose of this study is to assess the rationality of the use of antibiotics from inpatients in one hospital in Cimahi, West Java. The research about rationality analysis of antibiotics at pediatric inpatient in one of the hospitals in Cimahi was done retrospectively use descriptive analysis design. The data source was the medical record of a patient who treated at the children's inpatient ward from January through March 2017. The result shows that 39\% of infected patients were children under one-year-old. Three significant cases of diseases that occurred in the period were bronchopneumonia, typhoid fever, and typhoid fever+bronchopneumonia. Antibiotics therapy was given as single therapy as well as combination, where cefotaxime (51\%) and ceftriaxone $(42 \%)$ were the most antibiotics widely used as single therapy. Antibiotic use at children inpatient ward during the period January - March 2017 on bronchopneumonia, typhoid fever, and typhoid fever + bronchopneumonia patients was not $100 \%$ rational referring to criteria: correct diagnosis, correct indication, the correct drug of choice, correct dosage, correct method, and correct time interval of drug administration.
\end{abstract}

Received: October $10^{\text {th }} 2019$

Accepted: October 31 th 2019

Published: November 14th 2019

(C) 2019 Vina Septiani, Pudjiastuti Kartidjo, Fenny Asri Nurdiani. Published by Institute for Research and Community Services Universitas Muhammadiyah Palangkaraya. This is an Open Access article under the CC-BYSA License (http:/ / creativecommons.org/licenses/by-sa/4.0/). DOI: https://doi.org/10.33084/bjop.v2i2.1044.

\section{INTRODUCTION}

According to the World Health Organization, the use of drugs is rational if the patient gets medication as needed, in a sufficient period, and at the lowest price (OforiAsenso \& Agyeman, 2016). The use of the drug is irrational if the possibility of negative impacts received by patients is more significant than its benefits, such as clinical impact, for example, side effects and bacterial resistance, and economic impacts, such as costs are not affordable (Llor \& Bjerrum, 2014).

Antibiotic resistance remains a significant public health concern, and appropriate antibiotic use is an important health care quality goals (Hersh et al., 2013). Antibiotic resistance initially occurred at the hospital level, but slowly also developed in the community environment
(Davies \& Davies, 2010). Antibiotic resistance is also occurring in children in different countries, especially in developing countries (Zaman et al., 2017).

Prescribing of antibiotics for children only when benefits are proven scientifically. In practice, antibiotics do not need to be prescribed to children for high fever, inflammation of the throat, and diarrhea caused by viral infections (Levy-Hara et al., 2011). The selection of antibiotics depends not only on the spectrum but also the pharmacological properties, the potential for resistance, the safety profile, and the price (Jog, 2016). Appropriate antibiotic use is possible if health workers and the public have access to reliable and unbiased drug information. Universal access to reliable information about medicines can be achieved and must be the basis of efforts to promote rational prescriptions (Maiti et al., 2015). 
To ensure that patients get a rational treatment, especially the use of antibiotics in children, it is necessary to analyze the rationality of antibiotics usage in one of the hospitals in Cimahi, West Java. The purpose of this study is to assess the rationality of the use of antibiotics from inpatients in one hospital in Cimahi.

\section{MATERIALS AND METHODS}

The study was conducted using descriptive analysis design, which was carried out retrospectively. The source of research data is the medical record of the patient treated at the children's inpatient ward in one of the general hospitals in Cimahi. The research was conducted from June until August 2017. The population is a pediatric patient who treated in the children Inpatient ward. Inclusive criteria are pediatric patient aged $\leq 14$ years both male and female treated in children inpatient ward during the period from January to March 2017 and get antibiotic therapy, while the exclusive criteria are patients of children aged $\leq 14$ years both male and female treated in children inpatient ward during the period from January to March 2017 which did not get antibiotic.

The collected data is analyzed to get the results of the rationality analysis of antibiotics to use in one of the hospitals in Cimahi, including:

1. Patient and drug characteristics

Patient characteristics include the number of patients, age, gender, payment status, diagnosis, and discharge status. The characteristics of the drug include the type and amount of antibiotic use.

2. The rationality of the use of antibiotic

Analysis of the rational use of antibiotics includes the following criteria:

a. Appropriate diagnosis

The drug is given based on the right diagnosis. The diagnosis is made by a physician who treats the patient. b. Appropriate indication

It is said to be an accurate indication when antibiotics are given to patients with symptoms of a bacterial infection.

c. Appropriate drug of choice

Selection of drugs based on therapeutic effect according to the patient's disease.

d. Appropriate dosage regimen

The administered dose is not excessive or subdosage.

e. Appropriate route of administration

The chosen method of drug administration must be following the prescribed medication and the patient's condition.

f. Appropriate time interval of administration

The time interval of drug administration must be adjusted to the prescribed medication and the patient's condition.

Reference used in the analysis of rational antibiotics use is Basic and Clinical Pharmacology $12^{\text {th }}$ edition (Katzung et al., 2011).

\section{RESULTS AND DISCUSSION}

\section{Patient characteristics and medication}

Based on the results of the study, there were 165 patients included in the inclusion criteria. Patient characteristics are presented in Table I. Table I shows the patient's demographic data in the children's inpatient ward in one of the public hospitals in Cimahi during the period from January to March 2017. A total of $54 \%$ of patients were males, whereas female patients were $46 \%$. Based on payment status, $61.8 \%$ is Badan Penyelenggara Jaminan Sosial Kesehatan (BPJS Kesehatan, National Health Insurance) patient because of the hospital as a regional general hospital is one of the health service facilities that accept BPJS Kesehatan patients. However, there are also $31.5 \%$ of patients with public payment status, and the 
remaining 6.7\% are Keluarga Miskin Daerah (Gakinda, Regional Health Insurance) patients.

By age, 39\% of children hospitalized from January to March 2017 were patients aged 0-1 years. The perfect immune system can cause a high incidence of infections in the age range is not yet developed. This is supported by data showing that the higher the age, the lower the incidence of infection, as shown in Table I.

Patient discharge data is quite diverse, $48 \%$ cured, $46 \%$ improvement, $4 \%$ not cured, while each as much as $1 \%$ died and no information discharge status. Infection is a diagnosis that can be cured. Therefore, an appropriate antibiotic therapy can eradicate the bacteria that cause infection and can cure the patient. However, there are also patients with improvement discharge status. Patients with improvement discharge status are given antibiotic therapy upon discharge. Patients with not cured discharge status are patients who discharge by their request, or the term patient wants to go home forcefully. These patients generally are patients with public payment status, who ask to go home from the hospital before being allowed by the doctor due to costs related constraints. Some patients discharged from the dead condition. The patient who dies is patient with complications. Patient with no information in discharge status is known from the absence of information on discharge status in the patient's medical record. This indicates that some medical records do not contain complete data.

Table I. Patient characteristics

\begin{tabular}{llc}
\multicolumn{1}{c}{ Variable } & \multicolumn{1}{c}{ Category } & Frequency \%) \\
\hline Gender & Male & 54 \\
\multirow{3}{*}{ Age } & Women & 46 \\
& 0-1 years old & 39 \\
& 2-3 years old & 17 \\
4-5 years old & 13 \\
& 6-7 years old & 12 \\
8-9 years old & 7 \\
& 10-11 years old & 7 \\
Payment Status & 12-13 years old & 5 \\
& 14-15 years old & 1 \\
& BPJS Kesehatan & 61.8 \\
& Public & 31.5 \\
& Gakinda & 6.7 \\
\hline
\end{tabular}

\begin{tabular}{llc}
\hline Discharge Status & Cured & 48 \\
& Improvement & 46 \\
& Not cured & 4 \\
& Died & 1 \\
& No information & 1 \\
\hline
\end{tabular}

Cases of infectious diseases in the pediatric inpatient during the period of January to March 2017 are quite diverse, however there are three diagnoses with the highest prevalence compared to other diagnoses, namely bronchopneumonia as many as 56 cases, typhoid fever as many as 25 cases, and typhoid fever+bronchopneumonia as many as 17 cases, as shown in Figure 1.

Antibiotics for therapy in the children inpatient ward during the period of January to March 2017 are given in a single or a combination. The most antibiotics given singly are cefotaxime by $51 \%$, and ceftriaxone by $42 \%$. Both are third-generation cephalosporin antibiotics. Cephalosporin is a beta-lactam antibiotic with broadspectrum activity. Compared to the previous class of antibiotics, cephalosporins have an excellent pharmacokinetic profile and low toxicity (Jum'a \& Karaman, 2015). Cephalosporins work by influencing proteins that are important for the synthesis of bacterial cell walls. Cephalosporins are divided into several generations based on target organisms (Kohanski et al., 2010). A study showed that antibiotics that were widely prescribed for children aged $<12$ years were penicillins, cephalosporins, and macrolides (Vaz et al., 2014).

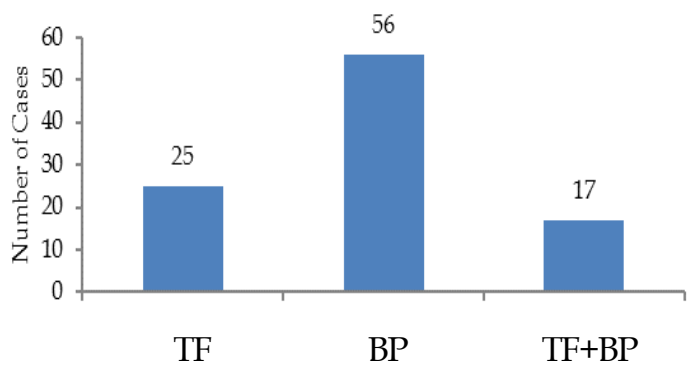

Figure 1. The three most diagnoses with the highest prevalence 
In the hospital, cefotaxime is used in bronchopneumonia patients, whereas ceftriaxone is given for patients with a diagnose of typhoid fever. Bronchopneumonia and typhoid fever are the two most diagnoses obtained, as seen in Figure 2. Bronchopneumonia is the clinical manifestation of pneumonia that is most common in children. Bronchopneumonia is an infectious disease that causes death in children under five years (Zec et al., 2016). Cefotaxime is a third-generation cephalosporin that has broad-spectrum activity and is widely used in the treatment of pneumonia (Yayan et al., 2015). The results of other studies show that the most widely used therapy for pneumonia is antibiotics of penicillin and first and third-generation cephalosporins (Zec et al., 2016). Ceftriaxone is a third-generation cephalosporin that has high effectiveness against Salmonella typhi and becomes the therapeutic standard of typhoid fever in various countries of the world, but this drug requires parenteral administration, therefore, it is considered less than ideal (Frenck et al., 2000).

The results of the study showed that several patients received combination antibiotic therapy. In general, the use of antibiotic combination aims to increase the effectiveness of antibiotics in eradicating bacteria. Also, the results of the study showed that there was an antibiotics replacement, which was generally due to the previous antibiotics that did not achieve the expected effect. This can be seen from the improvement of the patient's symptoms as well as from the results of examinations such as vital signs, laboratory tests, and others. Replacement antibiotics come from the same group of antibiotics or different groups of antibiotics.

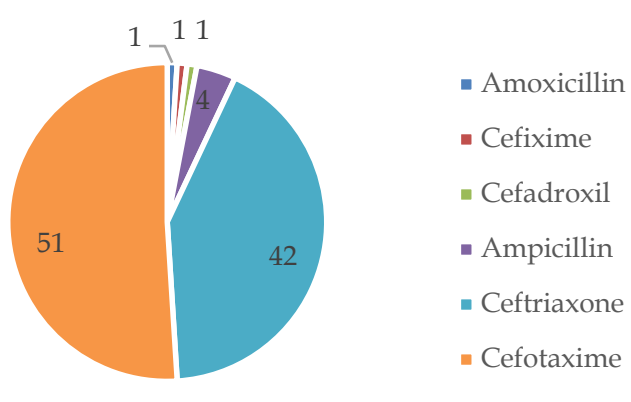

Figure 2. Type and percentage of antibiotics used

\section{Overview of the rationality of antibiotics use}

Rationality analysis of antibiotic use was carried out on the antibiotics used in the three most cases of the disease, namely bronchopneumonia (BP), typhoid fever (TF), and typhoid fever+bronchopneumonia (TF+BP). Table II shows the results for the accuracy of the diagnosis. Diagnosis data is based on the diagnosis that has been established by the doctor. Diagnosis of bronchopneumonia is carried out by conducting the thorax Postero-Anterior (PA), while typhoid fever is diagnosed with immunoserology, using the Widal test.

Table II. Review of the accuracy diagnosis

\begin{tabular}{|c|c|c|c|c|}
\hline 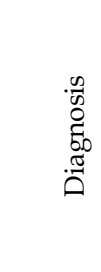 & 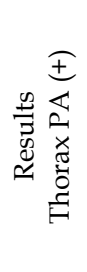 & 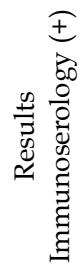 & 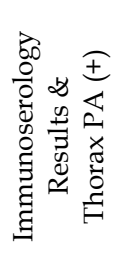 & 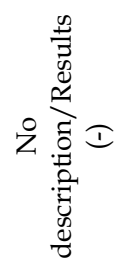 \\
\hline BP & 55 & - & - & 1 \\
\hline TF & - & 25 & - & 0 \\
\hline $\mathrm{TF}+\mathrm{BP}$ & - & - & 16 & 1 \\
\hline
\end{tabular}

Table III shows the results for the accuracy of the indication, drug of choice, and dosage. The selection of antibiotics is based on whether there is an indication for antimicrobial use (Slama et al., 2005). The analysis showed that all antibiotics used inpatient $\mathrm{BP}, \mathrm{TF}$, and $\mathrm{BP}+\mathrm{TF}$ are $100 \%$ correct, which means that antibiotics were used in cases of infection with diagnosis result that has been established, and 100\% correct drug of choice where the drug selected in accordance with the spectrum 
of action against microorganisms causing infectious cases and is a drug that complies with therapeutic guidelines and has an affordable price. Analysis of drug dosage showed as many as $11.22 \%$ subdosage and as many as 23.47\% excessive dosages (Katzung et al., 2011; HilalDandan \& Brunton, 2008). It may indicate the lack of rationality in giving antibiotics. However, this can also be caused by the patient having less or more bodyweight, thus affecting the administered dose, because generally the dose in child patients is calculated based on body weight.

The dose given can also be influenced by the severity of the infection suffered. Fewer dosages or subdosage can cause bacterial eradiation not to be achieved and potentially lead to resistance, while excessive dosage can increase the risk of adverse effects in patients. Research from Kaparang et al. (2014) showed that as many as 8.93\% of the use of antibiotics in children, the dosage is improper.

Table III. Review of the accuracy of the indication, drug of choice, and dosage

\begin{tabular}{|c|c|c|c|c|c|c|c|}
\hline \multirow[b]{2}{*}{ 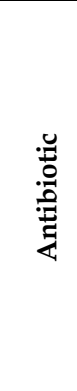 } & \multicolumn{3}{|c|}{$\begin{array}{c}\text { Assessment of } \\
\text { accuracy indications } \\
\text { and drugs of choice }\end{array}$} & \multicolumn{4}{|c|}{$\begin{array}{l}\text { Assessment of dosing } \\
\text { accuracy }\end{array}$} \\
\hline & 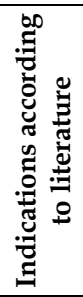 & 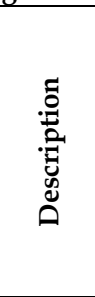 & $\approx$ & 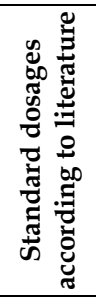 & 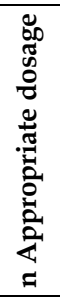 & 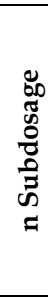 & 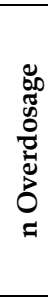 \\
\hline $\mathrm{A}$ & $\mathrm{BP}$ & Right & 2 & & 2 & - & - \\
\hline Cf & BP & Right & 23 & 蛋 & 23 & - & - \\
\hline $\mathrm{Cr}$ & BP & Right & 1 & 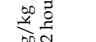 & 1 & - & - \\
\hline $\begin{array}{l}\mathrm{Cf} \text { to } \\
\mathrm{Ce}\end{array}$ & BP & Right & 9 & 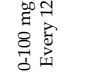 & 8 & - & 1 \\
\hline $\begin{array}{l}\mathrm{Cr} \text { to } \\
\mathrm{Ce}\end{array}$ & BP & Right & 1 & 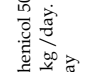 & - & 1 & - \\
\hline $\mathrm{Cd}$ & $\mathrm{BP}$ & Right & 1 & 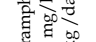 & - & 1 & - \\
\hline $\begin{array}{l}\text { Cf to } \\
\text { Ce to } \\
\text { Cx }\end{array}$ & BP & Right & 1 & 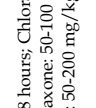 & 1 & - & - \\
\hline $\begin{array}{l}\text { Cf \& } \\
C x\end{array}$ & $\mathrm{BP}$ & Right & 2 & 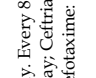 & - & - & - \\
\hline $\begin{array}{l}\text { Cf \& } \\
G\end{array}$ & $\mathrm{BP}$ & Right & 3 & 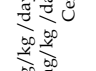 & 2 & - & - \\
\hline $\begin{array}{l}\text { A \& } \\
G\end{array}$ & $\mathrm{BP}$ & Right & 1 & 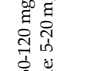 & - & - & 3 \\
\hline $\begin{array}{l}\mathrm{Cf} \& \\
\mathrm{Cx} \text { to } \\
\mathrm{Ce}\end{array}$ & $\mathrm{BP}$ & Right & 1 & 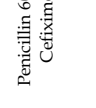 & - & - & 1 \\
\hline
\end{tabular}

\begin{tabular}{|c|c|c|c|c|c|c|c|}
\hline $\begin{array}{l}\text { Cf \& } \\
\text { G to } \\
\text { Cf \& } \\
C x\end{array}$ & BP & Right & 2 & & 1 & - & - \\
\hline $\begin{array}{l}\text { Cf \& } \\
\text { G to } \\
A\end{array}$ & BP & Right & 1 & & - & - & - \\
\hline $\begin{array}{l}\text { Cf \& } \\
\text { G to } \\
\text { Ce }\end{array}$ & BP & Right & 4 & & - & - & 2 \\
\hline $\begin{array}{l}\text { A \& } \\
\text { Cf to } \\
M\end{array}$ & BP & Right & 1 & & - & - & - \\
\hline $\begin{array}{l}\text { Cf to } \\
\text { A \& } \\
\text { G to } \\
\text { Ce }\end{array}$ & BP & Right & 1 & & - & - & 1 \\
\hline $\begin{array}{l}\text { Cf to } \\
\text { A }\end{array}$ & BP & Right & 1 & & - & - & - \\
\hline $\begin{array}{l}\text { Cf-M- } \\
\text { Ce- } \\
\text { Cr- } \\
\mathrm{Ce}\end{array}$ & BP & Right & 1 & & 1 & - & 3 \\
\hline A & $\mathrm{TF}$ & Right & 1 & & - & - & - \\
\hline $\mathrm{Cr}$ & $\mathrm{TF}$ & Right & 11 & & - & - & 1 \\
\hline $\mathrm{Cr}$ & $\mathrm{TF}$ & Right & 1 & & - & - & - \\
\hline $\begin{array}{l}\text { Cr to } \\
\mathrm{Ce}\end{array}$ & $\mathrm{TF}$ & Right & 8 & & - & - & 1 \\
\hline $\begin{array}{l}\text { Cf to } \\
\mathrm{Cr}\end{array}$ & $\mathrm{TF}$ & Right & 1 & & - & - & - \\
\hline $\begin{array}{l}\text { Ce to } \\
\mathrm{Ch}\end{array}$ & $\mathrm{TF}$ & Right & 1 & & - & - & - \\
\hline $\begin{array}{l}\text { Ch to } \\
\text { Cf }\end{array}$ & $\mathrm{TF}$ & Right & 1 & & 1 & - & - \\
\hline $\begin{array}{l}\text { Ch \& } \\
\mathrm{Cr}\end{array}$ & $\mathrm{TF}$ & Right & 1 & & - & 1 & - \\
\hline $\mathrm{Ce}$ & $\mathrm{BP}+\mathrm{TF}$ & Right & 2 & & - & - & - \\
\hline $\mathrm{Cr}$ & $\mathrm{BP}+\mathrm{TF}$ & Right & 4 & & - & - & 1 \\
\hline $\mathrm{Cf}$ & $\mathrm{BP}+\mathrm{TF}$ & Right & 4 & & 5 & - & 7 \\
\hline $\begin{array}{l}\text { Cf to } \\
\mathrm{Cr}\end{array}$ & $\mathrm{BP}+\mathrm{TF}$ & Right & 3 & & 1 & - & - \\
\hline $\begin{array}{l}\text { Cr to } \\
\mathrm{Ce}\end{array}$ & $\mathrm{BP}+\mathrm{TF}$ & Right & 3 & & 4 & 3 & - \\
\hline $\begin{array}{l}\mathrm{T} \text { to } \\
\mathrm{Cr}\end{array}$ & $\mathrm{BP}+\mathrm{TF}$ & Right & 1 & & 1 & - & - \\
\hline Total & 98 & Total & 98 & Total & 64 & 11 & 23 \\
\hline$\therefore$ & \& & $\therefore$ & 음 & $\therefore$ & $\begin{array}{l}\ddot{\infty} \\
\text { ம் }\end{array}$ & 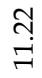 & ने \\
\hline
\end{tabular}

A: Ampicillin; Cd: Cefadroxil; Ce: Cefixime; Cf: Cefotaxime; $\mathrm{Ch}$ Chloramphenicol; Cr: Ceftriaxone; Cx: Cloxacillin; G: Gentamicin; M: Meropenem; T: Thiamphenicol

Table IV shows the review of the accuracy of the method and time interval of drug administration. Results of the analysis showed that the method of antibiotic administration was $100 \%$ correct, while as many as $56.12 \%$, the time interval of antibiotic administration was improper (Katzung et al., 2011). It may indicate a deficiency in the rationality of antibiotics administration. This can also be caused by nurses administering 
medication, not according to the schedule. The method of administering antibiotics should be adjusted to the condition of the patient because there are pediatric patients who cannot use drugs orally. Antibiotic is drugs with a specific time interval of administration, generally expressed as every 6 hours, every 8 hours, every 12 hours, or every 24 hours. The time interval of antibiotic administration should be appropriate because each antibiotic has a different half-life and duration of action, as well as its levels in the blood, should be maintained to achieve the desired therapeutic effect (Levison \& Levison, 2009).

Table IV. Review of the accuracy of the route and time

\begin{tabular}{|c|c|c|c|c|c|c|c|}
\hline \multirow[b]{2}{*}{ 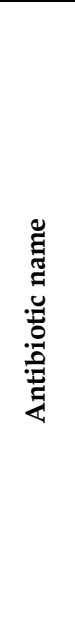 } & \multicolumn{3}{|c|}{$\begin{array}{l}\text { Accuracy of the } \\
\text { route of drug } \\
\text { administration }\end{array}$} & \multicolumn{4}{|c|}{$\begin{array}{c}\text { Accuracy of the time } \\
\text { interval of drug } \\
\text { administration }\end{array}$} \\
\hline & 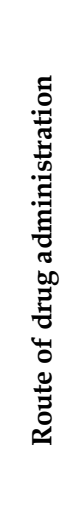 & 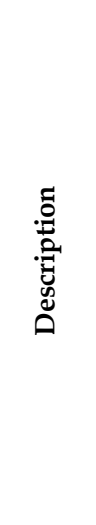 & $\approx$ & 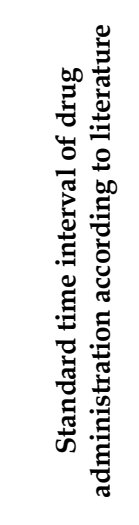 & 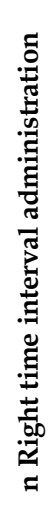 & 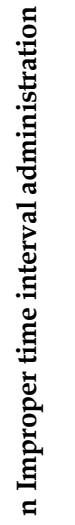 & 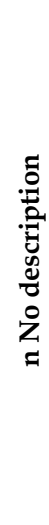 \\
\hline $\mathrm{A}$ & $\mathrm{P}$ & Right & 3 & $\begin{array}{l}\text { Every } 6 \text { or } \\
8 \text { hours }\end{array}$ & 1 & 2 & - \\
\hline $\begin{array}{l}A \& \\
G\end{array}$ & $\mathrm{P}$ & Right & 1 & $\begin{array}{l}\text { Every } 6 \\
\text { hours \& } \\
\text { per } 24 \\
\text { hours }\end{array}$ & 1 & - & - \\
\hline $\begin{array}{l}\text { A \& } \\
\text { Cf to } \\
M\end{array}$ & $\mathrm{P}$ & Right & 1 & $\begin{array}{l}\text { Every } 6 \\
\text { hours \& } 8 \\
\text { hours to } \\
\text { every } 8 \\
\text { hours }\end{array}$ & - & 1 & - \\
\hline $\mathrm{Ce}$ & $\mathrm{O}$ & Right & 2 & $\begin{array}{l}\text { Every } 12 \\
\text { hours }\end{array}$ & 1 & 1 & - \\
\hline $\begin{array}{l}\mathrm{Ce} \\
\text { to } \\
\mathrm{Ch}\end{array}$ & $\begin{array}{l}\mathrm{O} \text { to } \\
\mathrm{O} / \mathrm{P}\end{array}$ & Right & 1 & $\begin{array}{l}\text { Every } 12 \\
\text { hours to } \\
\text { every } 6 \\
\text { hours }\end{array}$ & - & 1 & - \\
\hline $\mathrm{Cr}$ & $\mathrm{P}$ & Right & 16 & $\begin{array}{l}\text { Every } 24 \\
\text { hours }\end{array}$ & 10 & 4 & 2 \\
\hline $\begin{array}{l}\mathrm{Cr} \text { to } \\
\mathrm{Ce}\end{array}$ & $\begin{array}{l}\mathrm{P} \text { to } \\
\mathrm{O}\end{array}$ & Right & 12 & $\begin{array}{l}\text { Every } 24 \\
\text { hours to } \\
\text { every } 12 \\
\text { hours }\end{array}$ & 6 & 6 & - \\
\hline Cf & $\mathrm{P}$ & Right & 28 & $\begin{array}{l}\text { Every } 8 \\
\text { hours }\end{array}$ & 13 & 13 & 2 \\
\hline
\end{tabular}

\begin{tabular}{|c|c|c|c|c|c|c|c|}
\hline $\begin{array}{l}\text { Cf to } \\
\mathrm{Ce}\end{array}$ & $\begin{array}{l}\mathrm{P} \text { to } \\
\mathrm{O}\end{array}$ & Right & 9 & $\begin{array}{l}\text { Every } 8 \\
\text { hours to } \\
\text { every } 12 \\
\text { hours }\end{array}$ & - & 9 & - \\
\hline $\begin{array}{l}\text { Cf to } \\
\text { Ce } \\
\text { to } \\
\text { Cx }\end{array}$ & $\begin{array}{l}\mathrm{P} \text { to } \\
\mathrm{O} \text { to } \\
\mathrm{P}\end{array}$ & Right & 1 & $\begin{array}{l}\text { Every } 8 \\
\text { hours to } \\
\text { every } 12 \\
\text { hours to } \\
\text { every } 6 \text { or } \\
8 \text { hours }\end{array}$ & - & 1 & - \\
\hline $\begin{array}{l}\mathrm{Cf} \text { to } \\
\mathrm{Cr}\end{array}$ & $\mathrm{P}$ & Right & 4 & $\begin{array}{l}\text { Every } 8 \\
\text { hours to } \\
\text { every } 24 \\
\text { hours }\end{array}$ & 2 & 2 & - \\
\hline $\begin{array}{l}\text { Cf to } \\
\text { A }\end{array}$ & $\mathrm{P}$ & Right & 1 & $\begin{array}{l}\text { Every } 8 \\
\text { hours to } \\
\text { every } 6 \text { or } \\
8 \text { hours }\end{array}$ & - & 1 & - \\
\hline $\begin{array}{l}\text { Cf \& } \\
C x\end{array}$ & $\mathrm{P}$ & Right & 2 & $\begin{array}{l}\text { Every } 8 \\
\text { hours \& } \\
\text { every } 6 \text { or } \\
8 \text { hours }\end{array}$ & - & 2 & - \\
\hline $\begin{array}{l}\text { Cf \& } \\
G\end{array}$ & $\mathrm{P}$ & Right & 3 & $\begin{array}{l}\text { Per } 8 \text { hours } \\
\& \text { per } 24 \\
\text { hours }\end{array}$ & - & 3 & - \\
\hline $\begin{array}{l}\mathrm{Cf} \& \\
\mathrm{Cx} \\
\text { to } \\
\mathrm{Ce}\end{array}$ & $\begin{array}{l}P \& \\
P \text { to } \\
O\end{array}$ & Right & 1 & $\begin{array}{l}\text { Every } 8 \\
\text { hours \& } \\
\text { every } 6 \text { or } \\
8 \text { hours \& } \\
\text { every } 12 \\
\text { hours }\end{array}$ & - & 1 & - \\
\hline $\begin{array}{l}\text { Cf \& } \\
\text { G to } \\
\text { Cf \& } \\
\text { Cx }\end{array}$ & $\mathrm{P}$ & Right & 2 & $\begin{array}{l}\text { Every } 8 \\
\text { hours \& } \\
\text { every } 24 \\
\text { hours to } \\
\text { every } 8 \\
\text { hours \& } \\
\text { every } 6 \text { or } \\
8 \text { hours }\end{array}$ & - & 2 & - \\
\hline $\begin{array}{l}\text { Cf \& } \\
\text { G to } \\
\text { A }\end{array}$ & $\begin{array}{l}\mathrm{P} \& \\
\mathrm{P} \text { to } \\
\mathrm{P} / \mathrm{O}\end{array}$ & Right & 1 & $\begin{array}{l}\text { Every } 8 \\
\text { hours \& } \\
\text { every } 24 \\
\text { hours to } \\
\text { every } 8 \\
\text { hours }\end{array}$ & - & 1 & - \\
\hline $\begin{array}{l}\text { Cf \& } \\
\text { G to } \\
\text { Ce }\end{array}$ & $\begin{array}{l}\mathrm{P} \text { to } \\
\mathrm{O}\end{array}$ & Right & 4 & $\begin{array}{l}\text { Every } 8 \\
\text { hours \& } \\
\text { every } 24 \\
\text { hours to } \\
\text { every } 12 \\
\text { hours }\end{array}$ & 1 & 3 & - \\
\hline $\begin{array}{l}\text { Cf to } \\
\text { A \& } \\
\text { G to } \\
\text { Ce }\end{array}$ & $\begin{array}{l}\text { P to } \\
P \& \\
P \text { to } \\
O\end{array}$ & Right & 1 & $\begin{array}{l}\text { Every } 8 \\
\text { hours to } \\
\text { every } 6 \text { or } \\
8 \text { hours \& } \\
\text { every } 24 \\
\text { hours to } \\
\text { every } 12 \\
\text { hours }\end{array}$ & - & 1 & - \\
\hline $\begin{array}{l}\text { Cf- } \\
\mathrm{M}- \\
\mathrm{Ce}- \\
\mathrm{Cr}- \\
\mathrm{Ce}\end{array}$ & $\begin{array}{l}\text { P-P- } \\
\text { O- } \\
\text { P-O }\end{array}$ & Right & 1 & $\begin{array}{l}\text { Every } 8 \\
\text { hours- } \\
\text { every } 8 \\
\text { hours- } \\
\text { every } 12 \\
\text { hours- } \\
\text { every } 24 \\
\text { hours- } \\
\text { every } 12 \\
\text { hours }\end{array}$ & - & 1 & - \\
\hline
\end{tabular}




\begin{tabular}{|c|c|c|c|c|c|c|c|}
\hline $\mathrm{Cd}$ & $\mathrm{P} / \mathrm{O}$ & Right & 1 & $\begin{array}{l}\text { Every } 8 \\
\text { hours }\end{array}$ & 1 & - & - \\
\hline $\begin{array}{l}\mathrm{Ch} \\
\text { to } \mathrm{Cr}\end{array}$ & $\begin{array}{l}\mathrm{O} / \mathrm{P} \\
\text { to } \mathrm{P}\end{array}$ & Right & 1 & $\begin{array}{l}\text { Every } 6 \\
\text { hours to } \\
\text { every } 24 \\
\text { hours }\end{array}$ & 1 & - & - \\
\hline $\mathrm{Ch}$ & $\mathrm{O} / \mathrm{P}$ & Right & 1 & Every 6 & 1 & - & - \\
\hline$\& \mathrm{Cr}$ & $\& P$ & & & $\begin{array}{l}\text { hours \& } \\
\text { per } 24 \\
\text { hours }\end{array}$ & & & \\
\hline $\begin{array}{l}\mathrm{T} \text { to } \\
\mathrm{Cr}\end{array}$ & $\begin{array}{l}\mathrm{P} / \mathrm{O} \\
\text { to } \mathrm{P}\end{array}$ & Right & 1 & $\begin{array}{l}\text { Every } 6 \\
\text { hours to } \\
\text { every } 24 \\
\text { hours }\end{array}$ & 1 & - & - \\
\hline Total & 98 & Total & 98 & Total & 39 & 55 & 4 \\
\hline å & $\underset{ }{8}$ & $\infty^{\circ}$ & 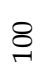 & 。 & $\begin{array}{l}\infty \\
\text { ஸे }\end{array}$ & $\begin{array}{l}\text { ㄱ. } \\
\text { ถึ่ }\end{array}$ & $\stackrel{\infty}{\infty}$ \\
\hline
\end{tabular}

A: Ampicillin; Cd: Cefadroxil; Ce: Cefixime; Cf: Cefotaxime; Ch: Chloramphenicol; Cr: Ceftriaxone; Cx: Cloxacillin; G: Gentamicin; M: Meropenem; T: Thiamphenicol; O: Oral; P: Parenteral

\section{CONCLUSION}

The use of antibiotics at children inpatient ward in one of general hospital in Cimahi during the period January to March 2017 in patients with bronchopneumonia, typhoid fever, and typhoid fever + bronchopneumonia is not $100 \%$ rational referring to the criteria of right diagnosis, right indication, right drug of choice, right dosage, right method and time interval of drug administration.

\section{APPROVAL OF ETHICS}

The Health Research Ethics Committee of the Faculty of Medicine of University of Padjadjaran (Reference number: 624/UN6.C10/PN/2017) has approved this research.

\section{ACKNOWLEDGMENT}

We are grateful to the Institute for Research and Community Service of Universitas Jenderal Achmad Yaniwhich has facilitated so that this research can be carried out well.

\section{REFERENCES}

Davies, J., Davies, D. 2010. Origins and Evolution of Antibiotic Resistance. Microbiology and Molecular Biology Reviews. 74(3):417-433. https://dx.doi.org/10.1128/MMBR.00016-10

Frenck, R.W.Jr., Nakhla, I., Sultan, Y., Bassily, S.B., Girgis, Y.F., David, J., Butler, T.C., Girgis, N.I., Morsy, M. 2000. Azithromycin versus ceftriaxone for the treatment of uncomplicated typhoid fever in children. Clinical Infectious Diseases. 31(5):1134-1138.

https://doi.org/10.1086/317450

Hersh, A.L., Jackson, M.A., Hicks, L.A., American Academy of Pediatrics Committee on Infectious Diseases. 2013. Principles of judicious antibiotic prescribing for upper respiratory tract infections in pediatrics. Pediatrics.

132(6):1146-1154. https://doi.org/10.1542/peds.2013-3260

Hilal-Danda, R., Brunton, L. 2008. Goodman and Gilman's Manual of Pharmacology and Therapeutics $2^{\text {nd }}$ Edition. New York: McGraw-Hill Education

Jog, P. 2016. 'Rationale' of Antibiotic Therapy - Think before you Ink! Indian Pediatrics. 53:775-777.

Jum'a, S., Karaman, R. 2015. Antibiotics. In Karaman, R. (Ed.) Commonly Used Drugs - Uses, Side Effects, Bioavailability $\mathcal{E}$ Approaches to Improve it $1^{\text {st }}$ Edition. New York: Nova Science Publishers. https://doi.org/10.13140/RG.2.1.5114.4804

Kaparang, P.C., Tjitrosantoso, H., Yamlean, P.V.Y. 2014. Evaluasi Kerasionalan Penggunaan Antibiotika Pada Pengobatan Pneumonia Anak Di Instalasi Rawat Inap RSUP Prof. DR. R. Kandou Manado Periode JanuariDesember 2013. Pharmacon. 3(3):247-254.

Katzung, B.G., Masters, S.B., Trevor, A.J. 2011. Basic and Clinical Pharmacology $12^{\text {th }}$ edition. New York: McGraw-Hill Medical.

Kohanski, M.A., Dwyer, D.J., Collins, J.J. 2010. How antibiotics kill bacteria: from targets to networks. Nature Reviews Microbiology. 8(6):423-435.

https://dx.doi.org/10.1038/nrmicro2333

Levison, M.E., Levison, J.H. 2009. Pharmacokinetics and Pharmacodynamics of Antibacterial Agents. Infectious Disease Clinics of North America. 
23(4):791-vii.

https://dx.doi.org/10.1016/j.idc.2009.06.008

Levy-Hara, G., Amabile-Cuevas, C.F., Gould, I., Hutchinson, J., Abbo, L., Saxynger, L., Vlieghe, E., Cardoso, F.L., Methar, S., Kanj, S., Ohmagari, N., Harbarth, S. 2011. "Ten Commandments" for the Appropriate use of Antibiotics by the Practicing Physician in an Outpatient Setting. Frontiers in Microbiology. 2:230.

https://dx.doi.org/10.3389/fmicb.2011.00230

Llor, C., Bjerrum, L. 2014. Antimicrobial resistance: risk associated with antibiotic overuse and initiatives to reduce the problem. Therapeutic Advances in Drug Safety. 5(6):229-241. https://dx.doi.org/10.1177/204209861455491 9

Maiti, R., Bhatia, V., Padhy, B.M., Hota, D. 2015. Essential Medicines: An Indian Perspective. Indian Journal of Community Medicine. 40(4):223-232. https://dx.doi.org/10.4103/0970-0218.164382

Ofori-Asenso, R., Agyeman, A.A. 2016. Irrational Use of Medicines-A Summary of Key Concepts. Pharmacy. 4(4):35. https://dx.doi.org/10.3390/pharmacy404003 5

Slama, T.G., Amin, A., Brunton, S.A., File, T.M.Jr., Milikovich, G., Rodvold, K.A., Sahm, D.F., Varon, J., Weiland, D.Jr., Council for Appropriate and Rational Antibiotic Therapy (CARAT). 2005. A clinician's guide to the appropriate and accurate use of antibiotics: The Council for Appropriate and Rational Antibiotic Therapy (CARAT) criteria. The American Journal of Medicine. Suppl 7A:1S-6S. https://doi.org/10.1016/j.amjmed.2005.05.00 7

Vaz, L.E., Kleinman, K.P., Raebel, M.A., Nordin, J.D., Lakoma, M.D., Dutta-Linn, M.M., Finkelstein, J.A. 2014. Recent Trends in Outpatient Antibiotic Use in Children. Pediatrics. 133(3):375-385.

https://dx.doi.org/10.1542/peds.2013-2903

Yayan, J., Ghebremedhin, B., Rasche, K. 2015. No Resistance to Penicillin, Cefuroxime, Cefotaxime, or Vancomycin in Pneumococcal Pneumonia. International Journal of Medical Sciences. 12(12):980-986. https://doi.org/10.7150/ijms.13203
Zaman, S.B., Hussain, M.A., Nye, R., Mehta, V., Mamun, K.T., Hossain, N. 2017. A Review on Antibiotic Resistance: Alarm Bells are Ringing. Cureus. 9(6):e1403.

https://dx.doi.org/10.7759/cureus.1403

Zec, S.L., Selmanovic, K., Andrijic, N.L., Kadic, A., Zecevic, L., Zunic, L. 2016. Evaluation of Drug Treatment of Bronchopneumonia at the Pediatric Clinic in Sarajevo. Medical Archives. 70(3):177-181. https://dx.doi.org/10.5455/medarh.2016.70. 177-181 